\title{
尿路感染症分離菌の膀胱定着に関する研究
}

聖マリアンナ医科大学泌尿器科学教室（主任：岩本晃明教授）

柳澤直子

\section{ADHESIVE PROPERTIES OF BACTERIA ISOLATED FROM PATIENTS WITH URINARY TRACT INFECTION TO THE URINARY BLADDER}

\author{
Naoko Yanagisawa \\ Department of Urology, St. Marianna University School of Medicine \\ (Director: Prof. T. Iwamoto)
}

(Background) Clinically isolated Staphylococcus epidermidis KK3-75, Enterococcus faecalis SMU-14, and Escherichia coli TF6-27 were subjected to test for bladder lodgments.

(Methods) Experimental cystitis on mice was investigated pathologically by light, confocal laser, and electron microscope after intravesical injection of cell suspensions of the strains. Bacterial affinities with bladder mucosal proteins and with extracellular components were detected by Western blot analysis.

(Results) Pathological findings of experimental cystitis revealed prominent infiltration of neutrophils except for those that were challenged with Enterococcus faecalis SMU-14. Capsulelike structures were demonstrated for the other two strains. Each strain showed histological tropism within the tissue sections, which correlated with the capability to bind the respective extracellular matrix components tested. Type I collagen bound only to cellular extracts of Enterococcus faecalis SMU-14 and Escherichia coli TF6-27, whereas fibronectin and type IV collagen bound only to those of Staphylococcus epidermidis KK3-75 and Enterococcus faecalis SMU-14. Bladder mucosal proteins had a variety of ability to bind cell surface proteins of each strain. Bacterial cell surface binding of all except for two of the bladder mucosal proteins detected was inhibited by extracellular matrix components.

(Conclusion) These experimental results suggest that the bacterial affinity of the bladder restricted by strain specific cell surface properties may be important for explanation in the difference of occurrence and progression of urinary tract infections caused by each strain.

Key words: experimental cystitis on mice, bacterial adherence, bladder proteins

要旨：(背景と目的) 臨床分離株であるStaphylococcus epidermidis KK3-75株, Enterococcus faecalis SMU-14株, Escherichia coli TF6-27株を用い, 膀胱定着性の違いを検討した.

（対象と方法）マウス実験的膀胱炎は，各菌液を経尿道的に接種して作製し，病理組織像を光学顕微 鏡，共焦点レーザー顕微鏡および電子顕微鏡にて観察した。また，菌体画分とマウス膀胱粘膜画分なら びに細胞外マトリックスの相互の結合性は Western blotting により検討した.

（結果）実験的膀胱炎組織での炎症反応の程度は, Enterococcus faecalis SMU-14株の場合では他の 2 菌株の場合に比べて弱かった. Staphylococcus epidermidis KK3-75株, Escherichia coli TF6-27株に は厚い萊膜様構造が観察された。菌体のマウス膀胱組織における分布は，各菌株で異なり，それぞれの 菌体画分と細胞外マトリックスとの結合性の違いに相関した。すなわち，I 型コラーゲンにはEnterococcus faecalis SMU-14株, Escherichia coli TF6-27株, フィブロネクチン, IV型コラーゲンにはStaphylococcus epidermidis KK3-75株, Enterococcus faecalis SMU-14株が結合性を示した. 菌体の表層 画分と膀胱粘膜画分との結合様式は，各菌株により異なった。さらに各菌体表層画分の膀胱粘膜画分へ 
の結合には，細胞外マトリックスにて阻害されるものを認めた。

（結論）これらの結果より, 各菌株の膀胱組織への定着の差は, 菌体表層の成分と膀胱粘膜画分㧍よ び細胞外マトリックスとの結合の違いに基づくことが示唆され, 各菌株による尿路感染症の発症進展の 違いに関与すると考えられる.

キーワード：マウス実験的膀胱炎，細菌の定着，膀胱蛋白

\section{緒 言}

細菌の臓器組織への定着は, 感染の成立における重 要な因子である. 細菌の宿主藏器組織への定着は, 細 菌の菌体表層成分と宿主側レセプターとの関係で論じ られている ${ }^{11}$. 細菌の臓器組織への定着性を担う病原 因子は，これまでにグラム陰性菌の線毛について多く の報告があり，宿主細胞の糖鎖を認識するといわれて いる ${ }^{2)}$. しかし, Escherichia coli (以下 E. coli と略)

の P 線毛の宿主側レセプターである D-Gal $\alpha$ (1-4)-D$\mathrm{Gal}$ を含む糖蛋白は腎に比して移行上皮では少ないこ とが知られており ${ }^{3)}$, 疫学的に, 急性膀胱炎で分離され る E. coli の $\mathrm{P}$ 線毛保有率は急性腎孟腎炎の場合に比 して低いことから，急性腎孟腎炎に対して，急性膀胱 炎の成立には E. coli の $\mathrm{P}$ 線毛の関与は少ないのでは ないかと考えられている4).

一方, 尿路感染症の起因菌は多種にわたるが，急性 単純性膀胱炎での菌種別分離頻度は E. coli が最も多 く, グラム陽性菌ではStaphylococcus epidermidis (以 下S. epidermidis と略) の分離頻度が高い ${ }^{5)}$. 一方, 複 雑性尿路感染症の起因菌としてはグラム陽性菌とブド ウ糖非発酵グラム陰性菌の分離頻度が高く，とくに Enterococcus faecalis (以下 E. faecalis と略) が検出 されることが多い6).しかしながら，尿路に対するグラ 么陽性菌菌体表層成分の定着因子について論じた報告 は少ない。

近年, 各種細菌の菌体表層の非線毛性成分と細胞外 マトリックスとの蛋白相互結合が注目されるように なった ${ }^{7)}$ そこで, 今回尿路感染症患者の尿由来 $S$. epidermidis, E. faecalis, E. coli 用いて, 菌株によ る膀胱定着性の相違を菌学的, 形態学的ならびに生化 学的立場から検討した。

\section{材料および方法}

\section{1. 使用菌株}

聖マリアンナ医科大学病院における急性膀胱炎患者 の尿より分離された $S$. epidermidis KK3-75株, E. faecalis SMU-14株, E. coli TF6-27株を用いた。 各菌 株は, api-STAPH, api-STREP, API 同定キット (Montalieu，Vercieu，France）を用いて菌種の同定
を行った。

\section{2. 使用動物}

4 週齢, 体重18～20g の雄の DD 系マウス(日本クレ ア）を使用し，免疫血清の作製には，体重1.62～1.88 $\mathrm{kg}$ の雌の日本白色ウサギ（日本クレア）を用いた。

3. マウス上行性膀胱炎の作製

各菌株を brain heart infusion (以下 BHI と略, Difco) 液体培地 $30 \mathrm{ml}$ にて $37^{\circ} \mathrm{C} 18$ 時間培養後, 冷却遠心 機にて $8,000 \times \mathrm{g} \cdot 15$ 分間遠心し，その沈渣を $0.01 \mathrm{M}$ PBS pH 7.4に再浮遊させ, 光電比色計 (Model ANA$7 \mathrm{~B}$, 東京光電) にて $420 \mathrm{~nm}$ の波長で $1.0 \mathrm{OD}$ に調整し た.この細菌浮遊液は平板法による計測で, $1.33 \sim 2.93 \times 10^{\circ} \mathrm{CFU} / \mathrm{ml}$ の生菌数を含有していた. Schaeffer ら ${ }^{8)}$ の方法により, マウスをネンブタール (大日本製薬) 麻酔下で, 上記の調整菌液 $0.05 \mathrm{ml}$ を $24 \mathrm{G}$ プラスチックカテーテルを用い, 経尿道的にマウス膀 胱内に接種した。

4. マウス上行性膀朕炎における膀胱内の生菌数の 測定

牧角9の方法により, マウスを屠殺し, 膀胱を無菌的 に摘出後, 重量を測定し, 滅菌生理的食塩水（以下生 食水と略） $1.0 \mathrm{ml}$ を加えてホモジェナイザーを用いて 摚汼し，均等浮遊液を作製，同液を生食水にて10倍段 階希釈した。希釈液はそれぞれマンニット食塩培地 (BBL), EF 培地(ニッスイ)およびマッコンキー培地 (栄研)を用いて培養し, 単位重量当たりの生菌数を算 出した. 菌接種28日後まで膀胱内における生菌数の消 長を経日的に算定した。

5. マウス上行性膀胱炎組織の観察

1）光学顕微鏡による観察

膀胱内の生菌数の測定と同様の方法で 1 群 5 匹のマ ウスを用いて上行性膀腅炎を作製し, 各菌株に対する コントロールとしては0.01M PBS pH 7.4を用いた。 細菌浮遊液および PBS 接種 $2,4 ， 6 ， 24$ 時間，3， 7，14日後にマウスを屠殺, 膀胱を摘出し，10\%ホル マリン液で固定した。薄切標本は May-GrünwaldGiemsa 染色した.

2）電子顕微鏡による観察 
同一検体を電子顕微鏡にて観察するため, それぞれ

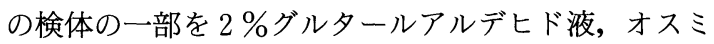
ウム液で固定し， $2 \%$ 寒天に包埋した。アルコールに て脱水, プロピレンオキサイドに封入, エポン樹脂に 置換し, 常法に従って切片を調整, 電子顕微鏡 (JEOL, Model 100-B 日本電子, 東京）にて観察した。

3）間接蛍光抗体法による観察

(1) 免疫ウサギ血清の作製

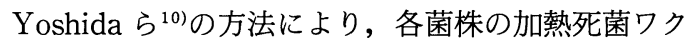
チンを調整，免疫ウサギ血清を作製した．S. epidermidis KK3-75株, E. faecalis SMU-14株, E. coli TF6-27株の生菌に対する各免疫ウサギ血清の凝集価 はマイクロタイター法で256倍, 1,024倍, 512倍, 死菌 に対する凝集価は1,024倍, 2,048倍, 1,024倍であった。

(2) ウサギ IgG 抗体の作製

免疫ウサギ血清を Protein A-Sepharose CL-4B (Pharmacia) を用いたカラムクロマトグラフィーに て分離, 0.01M PBS pH 7.4にて透析し, IgG(subclass 1，2，4）を精製した.

(3) 間接蛍光抗体法での共焦点レーザー顕微鏡によ る観察

光学顕微鏡による観察と同一の薄切標本を $10 \%$ ○゙ 全血清で60分間ブロック後, 各 $\operatorname{IgG}$ 抗体希釈液を一夜 反応させた。 0.01M PBS pH 7.4で洗浄後, fluorescein5-isothiocyanate 標識抗ウサギ免疫グロブリン (Cappel Research Products, Organon Teknika) の 50 倍希釈液を 30 分間反応させた. 0.01M PBS pH 7.4 で 5 回洗浄後, 共焦点レーザー顕微鏡 (LSM-GB200, Olympus）にて観察した。

\section{6. 使用菌株の菌体表層疎水性の検討}

Rosenberg ら ${ }^{11)} の$ 方法により, 菌体表層の疎水性 は, 菌体の水層からキシレン層への移行率として測定 ヒ, 各菌株ごとに 2 回算出, その平均值を求めた.

7. 菌体画分の細胞外マトリックス結合性の検討

1）菌体画分の調整

菌体画分の調整は, 以下の 3 通りの方法で行った ${ }^{12)}$. Sodium dodecyle sulfate (以下 SDS と略) - mercaptoethanol による可溶化は, 菌株を BHI 液体培地 にて $37^{\circ} \mathrm{C} 18$ 時間培養後0.01M PBS pH 7.4で洗浄した 全菌体を $2 \% \mathrm{SDS} ， 5 \% 2 \beta$-mercaptoethanol に添加, 3 分間加熱し, 可溶化したものを $0.45 \mu \mathrm{m}$ フィルター (Corning) で濾過滅菌した. Lysostaphin による抽出 は, SDS-mercaptoethanol 抽出と同様に収集した菌体 $1 \mathrm{~g}$ wet weight $k$ lysostaphin solution A $(50 \mathrm{mM}$
Tris- $\mathrm{HCl} \mathrm{pH} \mathrm{7.4,} 0.14 \mathrm{M} \mathrm{NaCl}$, lysostaphin $1 \mathrm{mg}$, DNase $2 \mathrm{mg}, 10 \mathrm{mM} N$-ethylmaleimide, $1 \mathrm{mM}$ phenylmethylsulfonyl fluoride (以下 PMSF と略)) $10 \mathrm{ml}$ を 添加， $37^{\circ} \mathrm{C} 30$ 分間インキュベーションし，さらに， lysostaphin $1 \mathrm{mg}$ を加え, 2.5時間インキュベーション した. $88^{\circ} \mathrm{C} 20$ 分間加熱にて酵素を非活化し, $1,350 \times \mathrm{g}$ ・ 20 分間冷却遠心，上清を $0.45 \mu \mathrm{m}$ フィルターで濾過滅 菌し, lysostaphin 抽出画分を得た。その沈渣は lysostaphin 非抽出画分として併せて実験に用いた。 Lithium chloride（以下 $\mathrm{LiCl}$ と略）による抽出は，同様に して収集した菌体1g wet weight を容量比10：1の

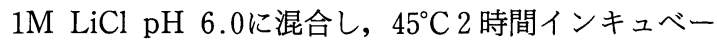
ションした. $3,600 \times \mathrm{g} \cdot 15$ 分間遠心，上清を $0.45 \mu \mathrm{m}$ フィルターで濾過滅菌し， $\mathrm{LiCl}$ 抽出画分を得た。その 沈椬は $\mathrm{LiCl}$ 非抽出画分として併せて実験に用いた。

2) Sulfo- $N$-hydroxysulfosuccinimide biotin 標識 細胞外マトリックスの作製

細胞外マトリックスは，フィブロネクチン (fibronectin from human plasma, Sigma), IV型コ ラーゲン (type IV collagen from human placenta, コスモバイオ), ラミニン (laminin from EngelbrethHolm-Swarm sarcoma, Sigma), I 型コラーゲン (Vitrogen from bovine dermal collagen, Celtrix) を用いた. Gaterman ら ${ }^{13)}$ の方法により, 各細胞外マト リック ス $100 \mu \mathrm{g} に 1 \mathrm{mM}$ sulfo- $N$-hydroxysulfosuccinimide (以下 S-NHS と略) -biotin (BIO-RAD), modified PBS (10mM Na $2 \mathrm{HPO}_{4}-\mathrm{NaH}_{2} \mathrm{PO}_{4}, 130 \mathrm{mM}$ $\mathrm{NaCl}) \mathrm{pH} 7.21 .0 \mathrm{ml}$ を添加, 室温で 1 時間インキュ

Fig. 1 Recovery of $S$. epidermidis KK3-75, E. faecalis SMU-14 and E. coli TF6-27 from bladders of mice after intravesical injection of $10^{7}$ CFU of the organisms.

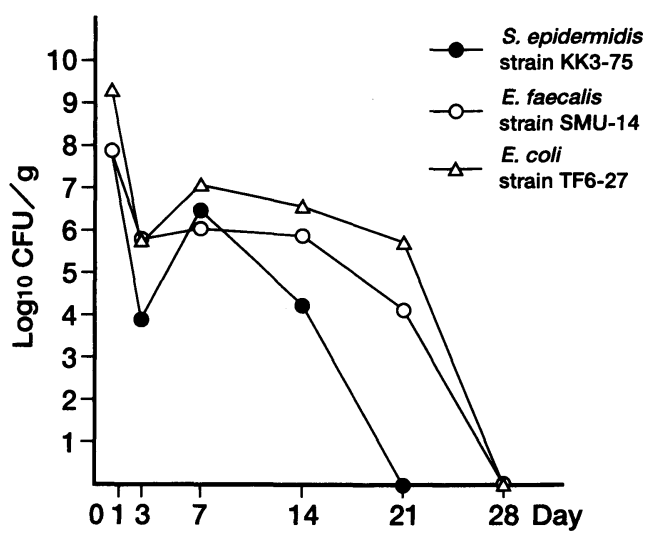


Fig. 2 Ultra-thin sections of the bladder of mice 4 hours after intravesical injection of $10^{7} \mathrm{CFU}$ of the organisms. A, S. epidermidis KK3-75; B, E. faecalis SMU-14; C, E. coli TF6-27 (bar $=1 \mu \mathrm{m})$.
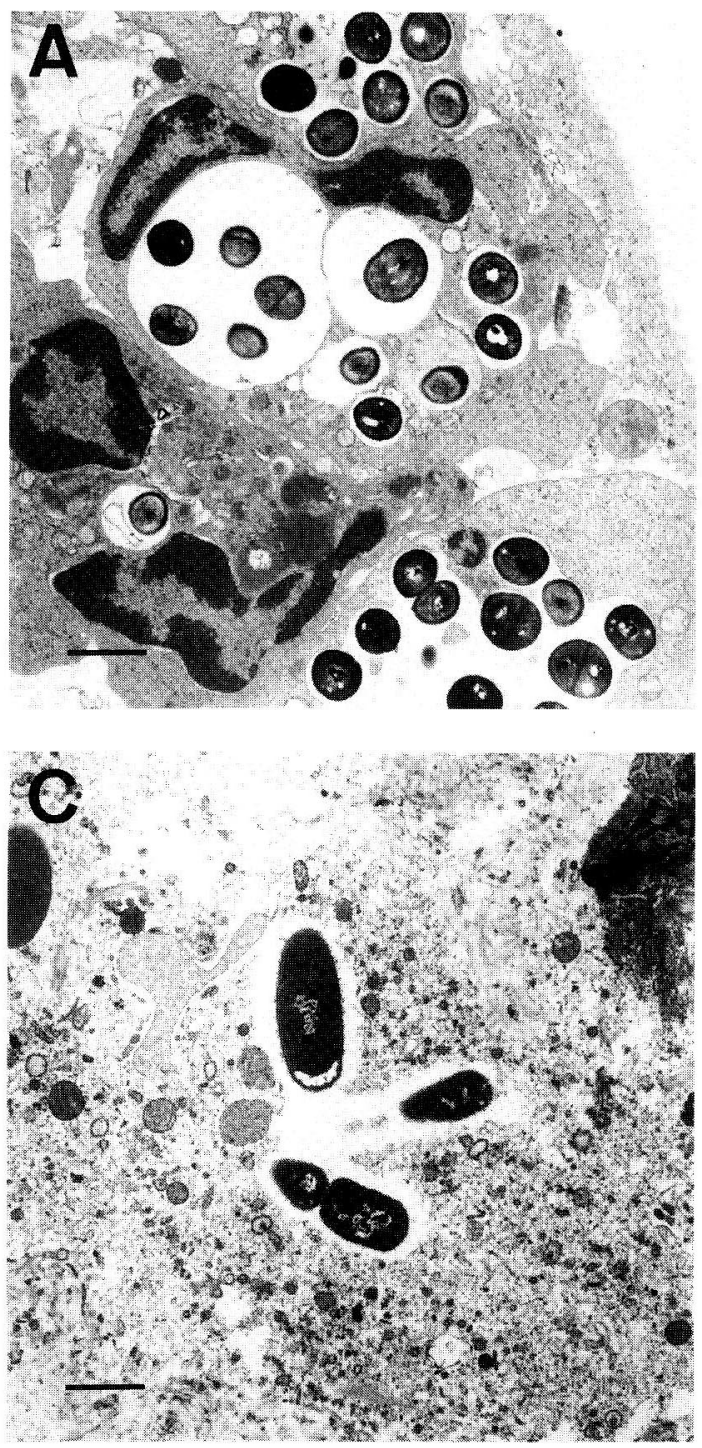

ベーションした.その後, 50mM Tris- $\mathrm{HCl}$ pH $7.5 を$ 加え, Sephadex G-25M (PD 10 column, Pharmacia) のカラムクロマトグラフィーに添加, modified PBS に て溶出し, ビオチン標識細胞外マトリックス（以下 B-ECM と略）を得た。

3）菌体画分とビオチン標識細胞外マトリックスの 結合実験

菌体からの各種抽出画分は, Laemmli ${ }^{14)} の$ 万法によ

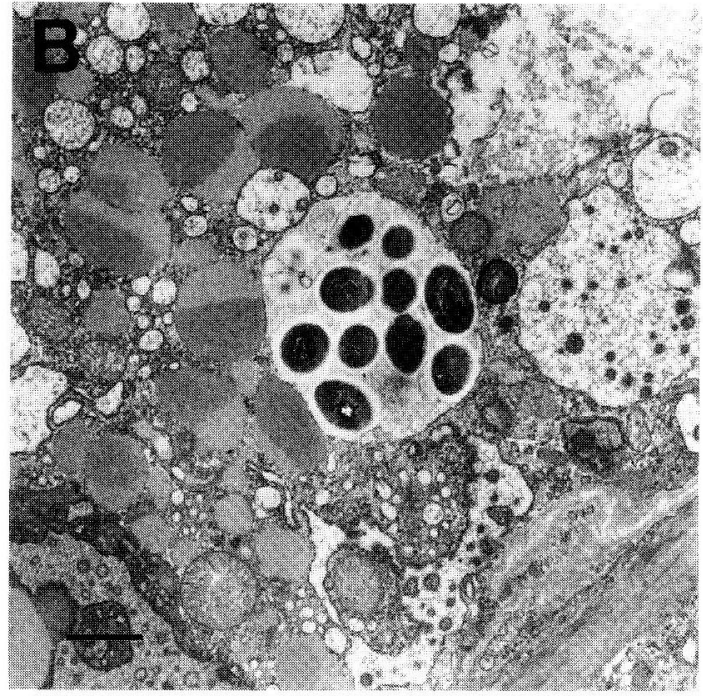

り $7.5 \%$ polyacrylamide gel を用いて SDSpolyacrylamide gel electrophoresis (以下PAGEと 略)を行い, Towbin ら ${ }^{15)}$ の方法により polyvinylidene difluoride membrane (以下PVDF-M と略, Millipore）を用いて Western blotting を行った。さらに， Gaterman ら ${ }^{13)}$ の方法により, PVDF-M を $1 \%$ bovine serum albumin (以下 BSA と略)-PBS にて一夜 $4{ }^{\circ} \mathrm{C}$ でブロックし, 0.01M PBS pH 7.4で洗浄した。次に, PVDF-M をB-ECM 2ml に0.5\%BSA-PBS $10 \mathrm{ml}$ 加えた溶液に入れ，室温で 2 時間インキュベーション した後，PBS-0.05\%Tween 20で 2 時間洗浄，再度 0.01M PBS pH 7.4で洗净した. 次いで, streptavidinalkaline phosphatase conjugate (以下 S-APase と略, BIO-RAD）2,000倍希釈液にて発色した菌体画分を観 察した。また，同様にして各菌体画分の Western blotting を行ったPVDF-M を Coomassie brilliant blue R-250（以下 CBB と略）にて染色した。 また，分子量 測定のためのマーカーとして, myosin (205kDa), $\beta$-galactosidase $(140 \mathrm{kDa})$, bovine serum albumin ( 83 $\mathrm{kDa})$, carbonic anhydrase $(45 \mathrm{kDa})$, soybean trypsin inhibitor $(32.6 \mathrm{kDa})$, lysozyme $(18 \mathrm{kDa})$, aprotinin (7.5kDa) (Kaleidoscope prestained standards, BIORAD）を用いた。

8. 膀胱粘膜画分の菌体表層画分結合性の検討

1) 膀胱粘膜画分の調整 
Fig. 3 Detection of strains by indirect immunofluorescence within bladders of mice 4 hours after intravesical injection of $10^{7} \mathrm{CFU}$ of the organisms. A, S. epidermidis KK3-75; B, E. faecalis SMU-14; C, E. coli TF6-27 (original magnification, $\times 200$ ).
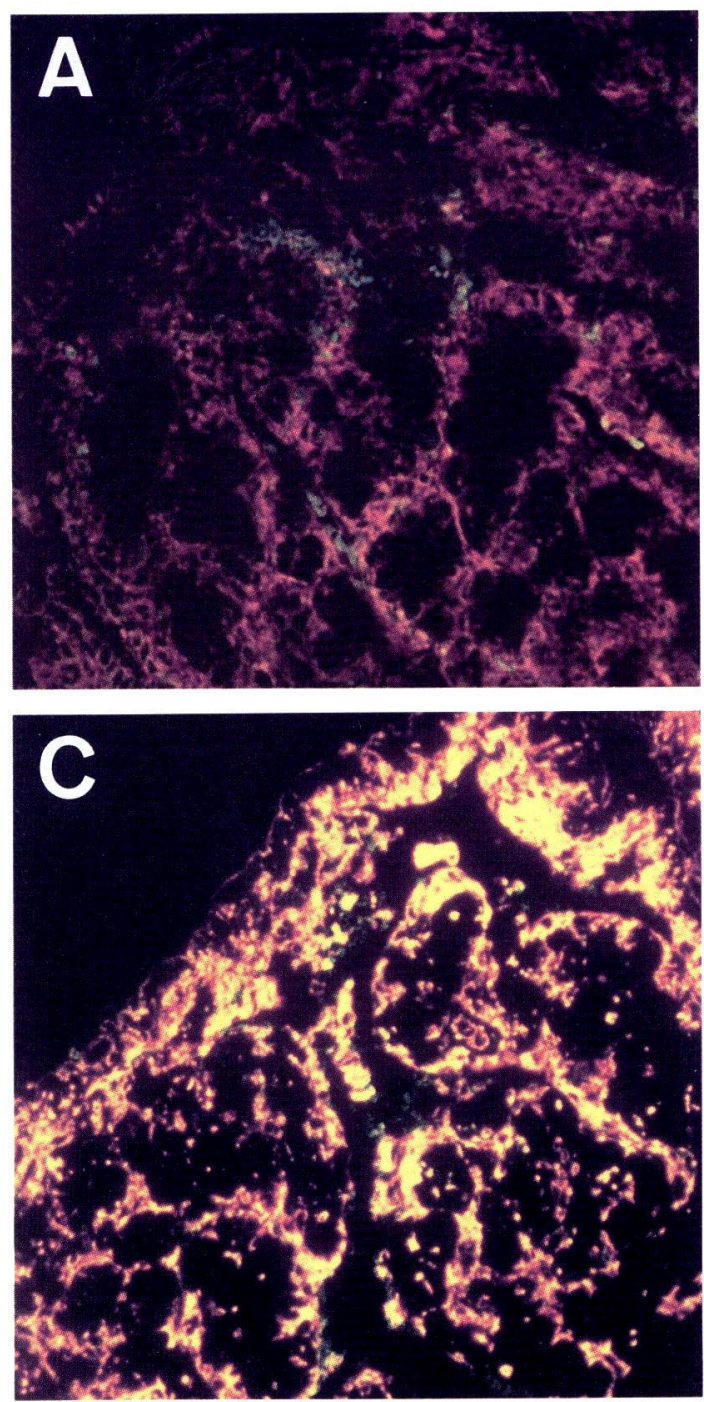

膀胱粘膜層は，マウスを屠殺して膀胱を摘出し， $0.01 \mathrm{M}$ PBS pH 7.4で洗浄後, 倒立顕微鏡下に膀胱粘 膜上皮層を可及的に切除, 細切した. Paulson ら ${ }^{16)}$ の方 法に基づき，組織片を0.15M NaCl，10mM EDTA,

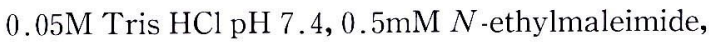
$0.5 \mathrm{mM}$ PMSF に採取し，ホモジェナイズした。

2）ビオチン標識菌体表層画分の作製

López-Ribot ${ }^{17)}$ の方法に基づき, SDS-

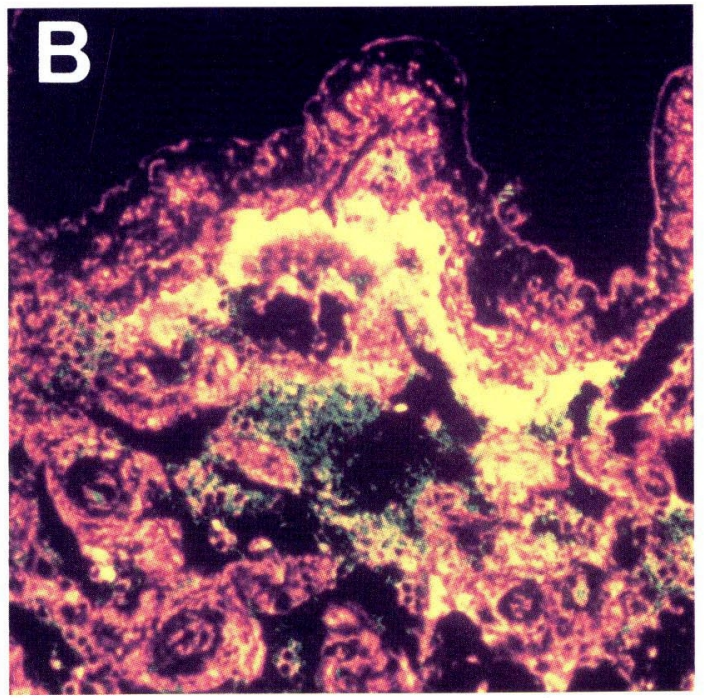

mercaptoethanol 抽出と同様に収集した菌体を 100 $\mathrm{mM}$ phosphate buffer $\mathrm{pH} 8.0$ に接種し, その $10^{8} \mathrm{CFU}$ / $\mathrm{ml}$ とS-NHS-biotin $0.4 \mathrm{mg} / \mathrm{ml}$ を室温で 2 時間イン キュベーションした. $8,000 \times \mathrm{g} ・ 15$ 分間遠心後, $10 \mathrm{mM}$ $N$-ethylmaleimide, $1 \mathrm{mM}$ PMSF, 0.01M PBS pH 7.4 $5 \mathrm{ml}$ を加え, 水槽冷却下で 1 分間超音波処理 $(10 \mathrm{kc})$ を行った後, $3,000 \times \mathrm{g} \cdot 15$ 分間遠心，上清を $0.45 \mu \mathrm{m}$ フィルターで濾過滅菌し，ビオチン標識菌体表層画分 （以下 B-CCF と略）を得た.

3）膀腅粘膜画分とビオチン標識菌体表層画分の結 合実験

膀胱粘膜画分を， $7.5 \% ， 10 \% ， 12.5 \%$ poly acrylamide gel を用いて SDS-PAGEを行い, PVDF.

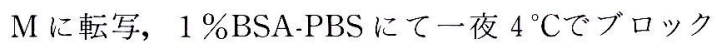
し, $0.01 \mathrm{M}$ PBS pH 7.4で洗浄した. さらに, B-CCF $10 \mu \mathrm{g}, 0.5 \% \mathrm{BSA}-\mathrm{PBS} 5 \mathrm{ml}$ を添加し, 室温で 1 時間イ ンキュベーションした. PBS-0.05\% Tween 20で 2 時 間洗浄, 再度0.01M PBS pH 7.4で洗浄した. S-APase 2,000 倍希釈液にて発色した膀胱粘膜画分を観察した。 また，同梯にして膀胱粘膜画分の Western blotting を 行ったPVDF-M をCBBにて染色した.

4）膀胱粘膜画分とビオチン標識菌体表層画分の結 合に対する吸収実験

膀胱粘膜画分は, B-CCF 結合実験と同様にして, 
Fig. 4 Distribution of cellular proteins of bacteria determined by Western blot analysis. A, S. epidermidis KK3-75; B, E. faecalis SMU-14 ; C, E. coli TF6-27. Lanes 1, Coomassie brilliant blue staining of bacterial protein extracts alone. Biotinylated extracellular matrix components with affinity between bacterial proteins : lanes 2, fibronectin; lanes 3 , type IV collagen; lanes 4, laminin; lanes 5 , type I collagen.

A

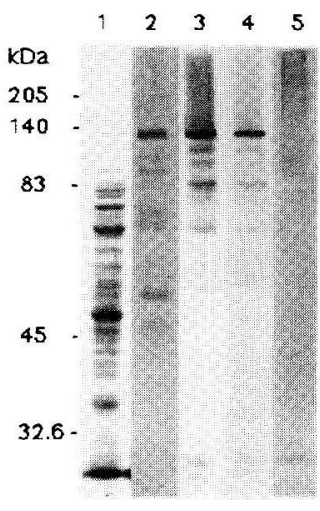

B

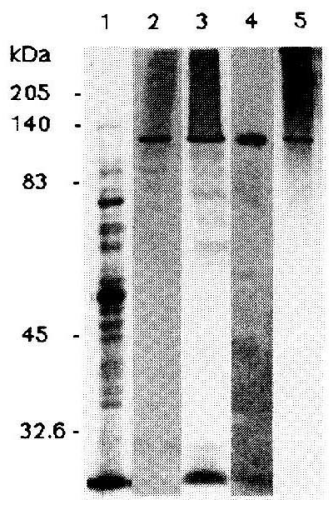

C

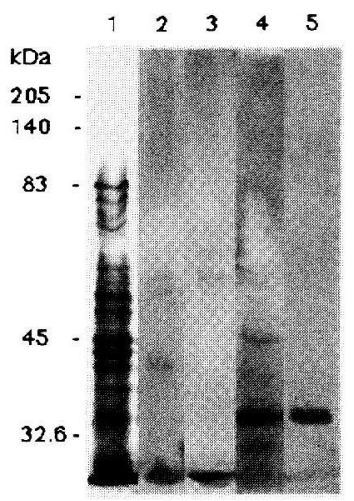

Western blotting 後ブロッキングを行った. B-CCF 10 $\mu \mathrm{g}$ に非標識細胞外マトリックス $50 \mu \mathrm{g}$ を添加し, $37^{\circ} \mathrm{C}$ 1 時間インキュベーションした.さらに0.5\%BSAPBS 5ml を加えた溶液に PVDF-M を入れ，室温で 1 時間インキュベーション, 同様にして膀胱粘膜画分を 発色した。

\section{結果}

1. マウス上行性膀胱炎における膀胱内の生菌数の 測定

S. epidermidis KK3-75株, E. faecalis SMU-14株, E. coli TF6-27株によるマウス実験的膀胱炎での膀胱 内の生菌数は, 菌接種21日後までの経過中, E. coli TF6-27株がもっとも多かった. E. faecalis SMU-14株 は同様に21日後まで膀胱内に生菌が残存したが，S. epidermidis KK3-75株は21日後には消失していた (Fig. 1).

\section{2. 使用菌株の菌体表層柾水性の検討}

菌体表層の疎水性の程度は, S. epidermidis KK3-75 侏は $11 \%$ ，E. coli TF6-27株は 8\%で親水性を示した。 E. faecalis SMU-14株は89\%で強い疎水性を示した.

\section{3. 実験的膀胱炎の病理組織像の観察}

1）光学顕微鏡による観察

S. epidermidis KK3-75株, E. faecalis SMU-14株, E. coli TF6-27株の実験的膀胱炎を May-GrünwaldGiemsa 染色により観察すると, 菌接種 2 時間後の膀
胱組織内に菌体は認めなかった。 4 時間後には，いず れの菌株の場合も，菌体は膀胱粘膜上皮層および粘膜 下層にみられた。また，粘膜下層の菌体周囲に好中球 浸潤を認めた。好中球浸潤の程度は，S. epidermidis KK3-75株, E. coli TF6-27株の場合に比心゙, E. faecalis SMU-14株の場合は軽度であった. なお,コントロール として PBS を接種した膀胱組織には炎症所見は認め なかった．以後 3 日まで， 3 菌株ともに粘膜上皮層お よび粘膜下層の菌数は減少したが，7日後には，粘膜 下層の菌数が再び増加した。いずれの菌株の場合も 14 日後には，組織内の菌数扝よび炎症所見は減少し，粘 膜下層に線維組織が増生した。

2）電子顕微鏡による観察

膀胱組織内の菌体を，菌接種 4 時間後に観察した。 各菌株の菌体外層には，電子密度のない萊膜多糖体様 haloが観察された (Fig. 2). その厚さは，S. epider. midis KK3-75株は200〜800nm，E. coli TF6-27株は 約400nm であり, E. faecalis SMU-14株は約200nm て 比較的薄い halo が認められた。

3）間接蛍光抗体法での共焦点レーザー顕微鏡によ る観察

菌体の膀胱組織内分布を, 菌接種 4 時間後に観察し た (Fig. 3). 菌体は，3菌株ともに膀胱粘膜上皮層， 粘膜下層の結合組織に沿って分布した．組織内の菌数 は, 3 菌株ともに粘膜上皮層に比して粘膜下層に多 
Fig. 5 Distribution of bladder mucosal proteins of mice seperated by SDS-PAGE on $10 \%$ polyacrylamide gels and determined by Western blot analysis. Cont., Coomassie brilliant blue staining of bladder mucosal proteins as control to the following affinity experiments. Biotinylated bacterial cell surface extracts with affinity between bladder mucosal proteins: A, S. epidermidis KK3-75; B, E. faecalis SMU-14; C, E. coli TF6-27. Lanes 1, biotinylated bacterial cell surface extracts alone. Unlabelled extracellular matrix components subjected to absorb cell surface proteins of each strain: lanes 2 , fibronectin; lanes 3 , type IV collagen; lanes 4, laminin; lanes 5, type I collagen.

A

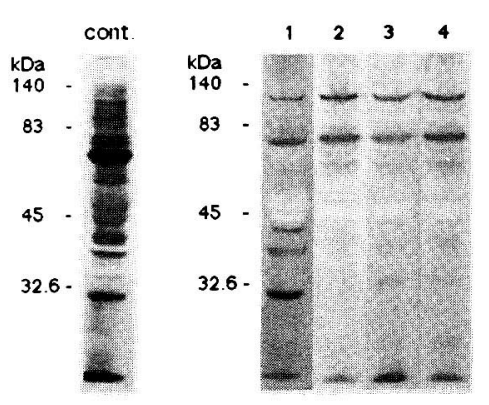

B

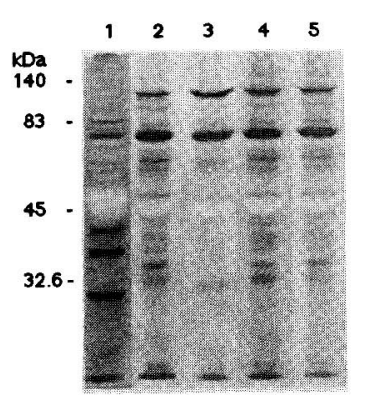

C

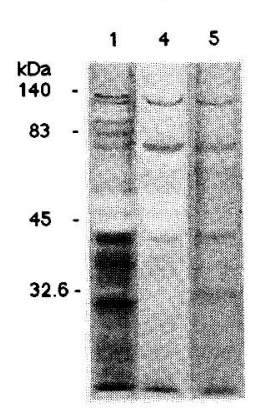

かった.さらに, 3 菌株では, 膀胱定着の様式が異なっ ていた. S. epidermidis KK3-75株は粘膜下層の結合組 織にびまん性に分布したが，E. faecalis SMU-14株, E. coli TF6-27株は粘膜下層の浅層では密に, 深層で は疎で網目様に分布した.さらに, E. faecalis SMU-14 株では粘膜上皮層直下の結合組織に濃密に定着した。 なお，強拡大による粘膜上皮層の観察では，3菌株と もに，菌体は粘膜上皮内腔面，粘膜上皮細胞間隙およ び粘膜の基底膜に分布した。

4. 菌体画分とビオチン標識細胞外マトリックスの 結合実験

各菌株が結合組織へ定着することに注目し, その構 成成分である各種細胞外マトリックスと菌体画分の結 合実験を行った. 各菌株の菌体画分は, Western blotting のCBB 染色により観察すると, 菌株により異な る複数の蛋白から構成されていた（Fig. 4, lanes 1). これらの菌体画分の細胞外マトリックスの結合性は, 3 菌株で異なった（Fig. 4, lanes 2，3，4，5）。すな わち, S. epidermidis KK3-75株はフィブロネクチン, IV型コラーゲン, ラミニン, E. faecalis SMU-14株は フィブロネクチン, IV型コラーゲン, ラミニン, I 型 コラーゲン, E. coli TF6-27株はラミニン, I 型コラー ゲンと結合した。各菌株の菌体画分で, 細胞外マトリッ クスと結合した主な菌体蛋白の分子量は, S. epidermidis KK3-75株では135kDa, E. faecalis SMU-14株
では130kDa，E. coli TF6-27株では38kDa であった. なお，これらの蛋白は, S. epidermidis KK3-75株と $E$. faecalis SMU-14株では, SDS-mercaptoethanol およ びLiCl により抽出されたが, lysostaphinにて抽出さ れず，E. coli TF6-27株では，いずれもの方法で抽出 された。

5. 膀胱粘膜画分とビオチン標識菌体表層画分の結 合実験および結合に対する吸収実験

膀胱粘膜画分は, コントロールとしてWestern blotting を CBB 染色にて観察すると, 複数の蛋白から構 成されていた (Fig. 5, cont.).この膀胱粘膜画分に, ビオチン標識した菌体表層画分を結合した. 膀胱粘膜 を $10 \%$ polyacrylamide gel を用いて分離すると（Fig. 5, lanes 1), 3 菌株は, 膀胱粘膜の115，72，40, 38, $36,30 \mathrm{kDa}$ 蛋白に, 共通して結合した.さらに, E. coli TF6-27株は, 膀胱粘膜の130，95，83kDa 蛋白と結合 した.なお, 膀胱粘膜画分を $12.5 \%$ polyacrylamide gel を用いて分離した場合には，3菌株は膀胱粘膜の 24 kDa 蛋白にも結合し, E. faecalis SMU-14株と E. coli TF6-27株はさらに膀胱粘膜の $20,16,11 \mathrm{kDa}$ 蛋白と結 合した.

各菌株を非標識細胞外マトリックスにて前処理し， 菌体表層の細胞外マトリックス結合蛋白を吸収した (Fig. 5).なお, 菌体画分とビオチン標識細胞外マト リックスの結合実験 (Fig. 4)にて，I 型コラーゲンは 
S. epidermidis KK3-75株に結合せず，フィブロネクチ ン，IV型コラーゲンは E. coli TF6-27株に結合しな かった。この結果に基づき，S. epidermidis KK3-75株 の菌体表層の吸収にはフィブロネクチン, IV型コラー ゲン, ラミニン (Fig. 5.A, lanes 2，3，4), E. faecalis SMU-14株にはフィブロネクチン, IV型コラーゲン, ラ ミニン，I 型コラーゲン (Fig. 5.B, lanes 2, 3, 4, 5), E. coli TF6-27株にはラミニン， I 型コラーゲン (Fig. 5.C, lanes 4，5）を使用した。これらの非標識 細胞外マトリックスにて吸収した 3 菌株の菌体表層画 分は, 膀胱粘膜の $115,72 \mathrm{kDa}$ 蛋白に結合した。この他 の膀胱粘膜画分への菌体表層の結合は阻害された。

\section{考 察}

細菌の藏器組織への定着性は, 細菌側の定着因子と, 宿主側のレセプターの相互作用により決まると考えら れている. 最初に, マウス実験的膀胱炎における膀胱 内の生菌数の動きから各種細菌の定着性をみた結果,

Fig. 1 に示すように各菌株によって異なり, S. epider midis KK3-75株は, 3 菌株中もっとも早期に膀胱内よ り消退し，本菌種による急性単純性膀胱炎の臨床像は 遷延するものが少ないとの黒坂ら ${ }^{18)}$ の報告を裏付けら れる.一方，マウス実験的膀胱炎の病理組織像を観察 すると, 各菌株により惹起される炎症反応の程度に差 がみられた.すなわち, S. epidermidis KK3-75株, E. coli TF6-27株に比べ, E. faecalis SMU-14株の場合は 好中球浸潤が軽度であった。これは，E. faecalis と E. coli によるマウス実験的腎孟腎炎で腎組織像を比較し た尾花ら ${ }^{199}$ の報告と同様である。これらの結果は，E. faecalis による尿路感染症では, 臨床症状が E. coliに よる場合よりも軽度であるという Felmingham ら ${ }^{20)}$ の報告と関連するものと思われる。

電子顕微鏡による観察では, 3 菌株の菌体外層には, 萊膜多糖体様の電子密度のない halo が観察され，その 大きさは, S. epidermidis KK3-75株, E. coli TF6-27 株で厚かった。一方 E. faecalis SMU-14株では, 莢膜 様構造は薄く,さらに, 膀胱への定着は長期間にみら れたことから，この菌株の抗食菌作用は萊膜様構造の 産生性のみによらないことが推測される ${ }^{21)}$. 一方, Svanborg-Edén ら ${ }^{22)} は, E$. coli において親水性株は莢 膜抗原を有し，親水性株の病原性は抗食菌作用に起因 すると報告している. Reifsteck ら ${ }^{23)}$ は Staphylococcus 属において親水性株の多くが萊膜を保有することを認 めており, 菌体の親水性による定着病原性は菌体表層 成分に依存するものと考えられている．菌体表層の疎
水性を観察すると, S. epidermidis KK3-75株, E. coli TF6-27株は親水性を示し, E. faecalis SMU-14株は強 い疎水性を示し, 菌体表層の親水性は莢膜様構造の大 小と相関した.

細菌の尿路への定着因子として, E. coli では線毛が 急性腎孟腎炎の成立に関与することが知られている. 数ある線毛のうち, P 線毛と I 型線毛はヒ卜腎尿細管 上皮に定着する。しかし，これらの線毛の膀胱上皮へ の定着は腎尿細管上皮への定着と比べて少ないことが 報告されている ${ }^{24)}$.この組織特異的な定着は, 2 種類の 線毛に対するレセプターの組織内における局在の相違 に基づくものと考えられ，宿主組織内のレセプターの 同定は, 細菌の組織病原性の理解に不可欠であること を示唆している，そこで, 細菌を結合する膀胱内のレ セプターについて, 菌株による比較を行った。細菌に 対する定着因子の組織内局在を明らかにする手法とし て, Korhonen ら ${ }^{24)}$ は, 菌株に対する抗体を用いた間接 蛍光抗体法がもっとも適しているとしているが, 今回 は各菌株に対して免疫ウサギ血清から IgG 抗体を精 製し, 間接蛍光抗体法により共焦点レーザー顕微鏡で 実験的膀胱炎組織を観察することにより, 菌体の組織 内における定着の部位が鮮明となった (Fig. 3)。菌体 は膀胼内接種 4 時間後に, 膀胱粘膜上皮層, 粘膜下層 の結合組織および粘膜の基底膜に定着した。菌体が膀 胱との接触後, 早期に基底膜より下層まで侵入する現 象は, E. coliによるマウス実験的膀胱炎で報告されて いるが25), 同様の所見が 3 菌株においてみられた.この 事実は, 細菌に対する膀胱組織側レセプターは, 膀胱 粘膜上皮, および結合組織の成分であることを示唆し ている.さらに, 膀胱組織内における菌体の定着分布 が 3 菌株で異なったことは, 菌体と組織内成分との間 に特異的なリガンドーレセプター結合が存在し, レセ プターの局在が菌株により異なることに基づくものと 考えられる。

膀胱の細胞外マトリックスと各菌株との結合性を検 討した。膀胱粘膜には, 複数の細胞外マトリックスの 存在が確認されており, 膀胱粘膜の基底膜, 粘膜下層 の血管内皮の基底膜にはラミニン, IV型コラーゲンが 線状に分布する ${ }^{26)}$. フィブロネクチンは膀胱粘膜の基 底膜と粘膜下層に分布し, 基底膜と粘膜下層との間に ネットワーク様構造を形成し ${ }^{27)}$, I 型コラーゲンは膀 胱粘膜下層に存在する ${ }^{28)}$. 膀胱粘膜下層の浅層では, コ ラーゲン線維は緻密層を形成し，その深層では，疎で 網目様に分布する ${ }^{29}$. Western blotting による細胞外 
マトリックスと菌体画分の結合実験の結果 (Fig. 4), フィブロネクチンは，S. epidermidis KK3-75株と E. faecalis SMU-14株に結合した. 菌体画分のフィブロネ クチン結合性は，これらの菌株が膀胱粘膜の基底膜お よび粘膜下層に定着した組織所見と一致した。ラミニ ンは 3 菌株, IV 型コラーゲンは S. epidermidis KK3-75株と E. faecalis SMU-14株に結合し， 3 菌株 ともに膀胱粘膜基底膜への定着性を有することを確認 し得た. I 型コラーゲンは, E. faecalis SMU-14株と E. coli TF6-27株に結合し, 両菌株の実験的膀胱炎組 織における粘膜下層浅層の密な定着の部位は，膀胱粘 膜のコラーゲン線維の分布と一致した．膀胱粘膜内の 細胞外マトリックスが細菌の特異的なレセプターであ ることは，細胞外マトリックスと各菌株の結合性と組 織所見が一致したことから明らかである。

膀胱粘膜への各菌株の結合性を膀胱粘膜画分と菌体 表層画分の結合実験により検討した (Fig. 5)。膀胖粘 膜中に存在する複数の蛋白が細菌に対してレセプター 活性を提供したが，細菌の標的蛋白は菌株により相違 があったことから，菌体表層画分と膀胱粘膜画分の間 に特異的な結合性が存在するものと考えられる.

次に，菌体側の定着因子について検討した．細胞外

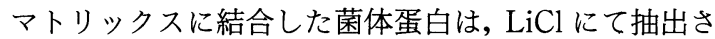
れた。このことは,これらの蛋白が細胞表層に位置し， 細胞壁に強固に存在しているものではないことを示唆 している ${ }^{12)}$. 細胞外マトリックスに結合した E. coli TF6-27株の $38 \mathrm{kDa}$ 蛋白は, $\mathrm{LiCl}$ および lysostaphin により抽出された。 S. epidermidis KK3-75株の135 $\mathrm{kDa}$ 蛋白および E. faecalis SMU-14株の $130 \mathrm{kDa}$ 蛋白 は, lysostaphin にて抽出されなかったことから，E. coli TF6-27株と他の 2 菌株では, 細胞表層中の細胞外 マトリックス結合蛋白の構造が異なるものと考えられ る.

Fig. 4 に示したように, 各使用菌株とも複数の細胞 外マトリックスに結合した。菌体の 1 つの蛋白が複数 の細胞外マトリックスと細胞外マトリックス以外の宿 主蛋白とも結合することはこれまでにも知られてお り,多機能性定着因子であると考えられている ${ }^{12)}$.そこ で, 各菌株の細胞外マトリックス結合蛋白が, 膀胱粘 膜画分とも結合する可能性を，非標識細胞外マトリッ クスによる吸収実験にて検討した. その結果(Fig. 5), 各菌株は, 非標識細胞外マトリックスにより菌体表層 の結合蛋白を吸収すると, 膀胱粘膜の $115,72 \mathrm{kDa}$ 蛋白 に結合し，この他の膀胱粘膜の蛋白との結合は阻害さ
れた.この阻害作用は, 菌体表層の細胞外マトリック スを結合する蛋白と, 膀胱粘膜画分を結合する蛋白が 同一であり，菌体表層蛋白に対する細胞外マトリック スとこの実験で吸収された膀胱粘膜画分との競合作用 が考えられる.さらに，菌体表層の細胞外マトリック スを結合する蛋白と, 膀胱粘膜画分を結合する蛋白が 近接に位置するために生じた立体障害であったとも考 えられる ${ }^{30)}$. 一方, 菌体の膀胱粘膜画分への結合には非 標細胞外マトリックス処理により阻害されないものを 認めたことから，菌体表層の膀胱粘膜と結合する蛋白 には，細胞外マトリックスを認識する蛋白と同一ない しは近接した位置にあるものと, 細胞外マトリックス 結合蛋白とは立体構造的に関連のない，2 種類の膀胱 粘膜結合蛋白があるのではないかと推測される。

以上の事実から, S. epidermidis, E. faecalis, E. coli の各菌株の膀胱定着には, 細菌側の細胞表層蛋白と膀 胱内の細胞外マトリックスおよび膀胱粘膜蛋白との相 互結合による機構が存在した。また，各菌株により膀 胱内の蛋白との結合性が異なったことは, 各菌株の細 胞表層成分の相違に基づくものと示唆される。これら の成績から, 細菌と膀胱内の蛋白の特異的な結合は, 起因菌の違いによる膀胱炎の臨床像の相違を解明する 上で重要であると考えられる。

稿を終えるにあたり, 御指導, 御校閲を賜りました岩本晃 明主任教授ならびに長田尚夫客員教授に深謝いたします。 また直接の御指導を賜りました本学微生物学教室嶋田甚五 郎主任教授, 大友俊允助教授に感謝いたします.さらに, 本 研究に御協力いただきました微生物学教室員の皆梯に御礼 申し上げます。

本論文の要旨は第84回日本泌尿器科学会総会, 第70回日 本感染症学会総会, 第 6 回尿路感染症研究会において発表 した.

1) Beachy, E.H.: Bacterial adherence: Adhesinreceptor interactions mediating the attachment of bacteria to mucosal surfaces. J. Infect. Dis., 143, 325-345, 1981.

2) Leffler, H. and Svanborg-Edén, C.: Glycolipid receptors for uropathogenic Escherichia coli on human erythrocytes and uroepithelial cells. Infect. Immun., 34, 920-929, 1981.

3) Breimer, M.E., Hansson, G.C. and Leffler, H. : The specific glycosphingolipid composition of human ureteral epithelial cells. J. Biochem., 98, 1169-1180, 1985.

4) Källenius, G., Möllby, R., Svenson, S.B., Helin, 
I., Hultberg, H., Cedergren, B. and Winberg, J. : Occurrence of P-fimbriated Escherichia coli in urinary tract infections. Lancet, ii, 1369-1372, 1981.

5）川村研二, 森山 学, 中島千聰, 芝 延行, 喜久山 明, 宮澤克人, 田中達朗, 池田龍介, 鈴木孝治, 津 川龍三：尿路感染症分離菌について一金沢医科大 学病院泌尿器科における 4 年間の推移一. 西日泌 尿, 55, 46-52, 1993.

6) 石原 哲, 安田 満, 多田晃司, 米田尚生, 伊藤康 久, 斉藤昭弘, 出口 隆, 栗山 学, 坂 義人, 河 田幸道: 複雑性尿路感染症由来 Enterococcus faecalis の臨床的検討と薬剤感受性について. 日化 療会誌, 43, 451-456, 1995.

7) Höök, M., Switalski, L.M., Wadström, T. and Lindberg, M.: Interactions of pathogenic microorganisms with fibronectin. in $\mathrm{Fi}$ bronectin, Mosher, D. ed., p295-308, Academic Press, Inc., New York, 1989.

8) Schaeffer, A.J., Schwan, W.R., Hultgren, S.J. and Duncan, J.L. : Relationship of type 1 pilus expression in Escherichia coli to ascending urinary tract infections in mice. Infect. Immun., 55, 373-380, 1987.

9）牧角和彦: 実験的尿路感染症に関する研究一Staphylococcus epidermidis によるマウス腎・膀胱内 定着について一。 日泌尿会誌, 84, 1602-1610, 1993.

10) Yoshida, K. and Ekstedt, R.D.: Antibody responce to Staphylococcus aureus in rabbits: Sequence of immunoglobulin synthesis and its correlation with passive protection in mice. J. Bacteriol., 96, 1540-1545, 1968.

11) Rosenberg, M., Gutnick, D. and Rosenberg, E. : Adherence of bacteria to hydrocarbons : A simple method for measuring cell-surface hydrophobicity. FEMS Microbiol. Lett., 9, 29-33, 1980.

12) McGavin, M.H., Krajewska-Pietrasik, D., Rydén, C. and Höök, M. : Identification of a Staphylococcus aureus extracellular matrixbinding protein with broad specificity. Infect. Immun., 61, 2479-2485, 1993.

13) Gaterman, S. and Meyer, H.-G.W.: Staphylococcus saprophyticus hemagglutinin binds fibronectin. Infect. Immun., 62, 4556-4563, 1994.

14) Laemmli, U.K.: Cleavage of structural proteins during the assembly of the head of bacteriophage T4. Nature (London), 227, 680-685, 1970.

15) Towbin, H., Staehelin, T. and Gordon, J. :
Electrophoretic transfer of proteins from polyacrylamide gels to nitrocellulose sheets : Produce and some applications. Proc. Natl. Acad. Sci. U. S.A., 76, 4350-4354, 1979.

16) Paulson, M., Aumailley, M., Deutzmann, R., Timpl, R., Beck, K. and Engel, J.: Lamininnidogen complex. Extraction with chelating agents and structural characterization. Eur. J. Biochem., 166, 11-19, 1987.

17) López-Ribot, J.-L. and Chaffin, W.L. : Binding of the extracellular matrix component entactin to Candida albicans. Infect. Immun., 62, 45644571, 1994.

18）黒坂公生：コアグラーゼ陰性ブドウ球菌 (CNS) 尿路感染症. 日本臨牀, 44, 2638-2643, 1986.

19）尾花芳樹, 西野武志：マウスを用いたEnterococcus faecalis の尿路感染性に関する研究. 第 2 報. 感染症誌, 65, 442-446, 1991.

20) Felmingham, D., Wilson, A.P.R., Quintana, A.I. and Grüneberg, R.N.: Enterococcus species in urinary tract infection.Clin. Infect. Dis., 15, 295 -301, 1992.

21) Jett, B.D., Huycke, M.M. and Gilmore, M.S. : Virulence of Enterococci. Clin. Microbiol. Rev., 7, 462-478, 1994.

22) Svanborg-Edén, C., Hagberg, L., Hull, R., Hull, S., Magnusson, K.-E. and Öhman, L. : Bacterial virulence versus host resistance in the urinary tracts of mice. Infect. Immun., 55, 12241232, 1987.

23) Reifsteck, F., Wee, S. and Wilkinson, B.J. : Hydrophobicity - hydrophilicity of staphylococci. J. Med. Microbiol., 24, 65-73, 1987.

24) Korhonen, T.K., Virkola, R., Westerlund, B., Holthöfer, H. and Parkkinen, J.: Tissue tropism of Escherichia coli adhesins in human extraintestinal infections. Curr. Top. Microbiol. Immun., 151, 115-127, 1990.

25）岡山 悟, 熊本悦明, 西尾 彰：実験的膀胱炎の感 染発症機序に関する研究. 第 1 報. 細菌侵入経過の 分析. 日泌尿会誌, 75, 1380-1390, 1984.

26) Wilson, C.B., Leopard, J., Nakamura, R.M., Cheresh, D.A., Stein, P.C. and Parsons, C.L. : Selective type IV collagen defects in the urothelial basement membrane in interstitial cystitis. J. Urol., 154, 1222-1226, 1995.

27) Pode, D., Alon, Y., Horowitz, A.T., Vlodavsky, I. and Biran, S.: The mechanism of human bladder tumor implantation in an in vitro model. J. Urol., 136, 482-486, 1986.

28) Ewalt, D.H., Howard, P.S., Blyth, B., Snyder, H. M. III, Duckett, J.W., Levin, R.M. and Macarak, 
E.J. : Is lamina propria matrix responsible for normal bladder compliance? J. Urol., 148, 544 -549, 1992.

29) Murakumo, M., Ushiki, T., Abe, K., Matsumura, K., Shinno, Y. and Koyanagi, T.: Threedimentional arrangement of collagen and elastin fibers in the human urinary bladder: A scanning electron microscopic study. J. Urol., 154, 251-256, 1995.

30) Sokurenko, E.V., Courtney, H.S., Abraham, S. N., Klemm, P. and Hasty, D.L.: Functional heterogeneity of type 1 fimbriae of Escherichia coli. Infect. Immun., 60, 4709-4719, 1992.

（1995年5月1日受付，10月7日受理） 